\title{
ウシカエル骨格筋の ribonuclease
}

\author{
阿部 靖子 \\ 日本医科大学第 1 生化学数室（主任 : 宿谷良一数㧐）
}

A ribonuclease from the skeletal muscle of bullfrog, Rana catesbeiana

\author{
Yasuko Abe \\ Department of Biochemistry, Nippon Medical School
}

\begin{abstract}
It has been known that several RNases occur in various tissues of vertebrates, although the role in the RNA metabolism of individual RNase is obscure. To study a possible mechanism involved in the regulation of RNase activity in the muscle during bullfrog metamorphosis, it was attempted to characterize a RNase from bullfrog muscle showing its activity in neutral region.

The neutral RNase in the cytosol fraction from bullfrog muscle occurs in two forms, one is a free form and the other a complex (latent form) of the RNase and its inhibitor. As compared with those of bullfrog liver, it was found that in the muscle cytosol fraction the greater part of the RNase is present as the complex and an excess amount of the RNase inhibitor as a free form. The partially purified RNase from the muscle cytosol fraction resembled to that of the liver in enzymatic properties.
\end{abstract}

Key words : RNase bullfrog muscle, RNase paritial purification, RNase characterization, RNase RNase inhibitor interaction

\section{緒雫}

功物組織 ribonuclease (RNase) には，醭素化学的 性啠および細胞内局在性を異にする 数種類の RNase の存在することが知られている(18). しかし,精製され たものは少なく，その生理的機能についてもほとんど わかっていない，長野ら"1)よび富田ら ${ }^{(2,18)} は$, ウシ カエル (Rana catesbeiana) 肝組織 RNase のうち 弱アルカリ域に至適 $\mathrm{pH}$ を有する RNase には少なく とも四種類あることを見い出し，それらを精製した．

そして, これらのうちの一つの RNase は, 哺乳動物 の肝 RNase と同様, 活性な遊離型 RNase と細胞内 inhibitor と結合した不活性結合型 RNase（潜在型 RNase）の二つの存在様式があること，後者は热，酸 および SH-試薬などの処理により活性化され遊離型 RNase 一と変換することなどを明らかにした．

著者は RNase の組織特異性および inhibitor との 反応性に関する研究の一環として，ウシカエル骨格筋 の中性域に至適 $\mathrm{pH}$ を有する RNase の性䋢を肝

Present address : 1st Department of Biochemistry Nippon Medical School, 1-1-5 Sendagi, Bunkyo-ku, Tokyo 113 Japan
RNase のそれと比较検討した.

\section{実験材料および方法}

実験材料：成熟ウシカエル（Rana catesbeiana） は東京都中央区築地の野沢商店より䀧入し，下肢骨格 胼を実験に用いた。醉母 tRNA は第一化学楽品，合 成 polynucleotide (poly $A$, polyG, poly $I$, poly $C$ および poly U), cytochrome c および $\alpha$-chymotrypsin は Boehringer 社, insulin は Sigma 社からそれぞ れ睡入した. CM-cellulose は Serva 社, Sephadex G-25 および G-50 は Pharmacia 社のものをそれぞ れ用いた。

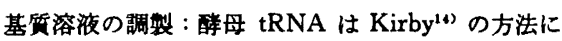
淮じ精製したのち，2\%水溶液として用いた．合成 polynucleotide はその $3 \%$ 水溶液を蒸留水に対し透 析したのち, 蒸留水を加えて $2 \%$ 水溶液として用い た。 なお，基梊瀑度は $1 \mathrm{mg} / \mathrm{ml}$ の波長 $260 \mathrm{~nm}$ にお ける吸光度を 23 として求めた.

本論文中で用いた省略記号は次のとおりです.

poly A; polyadenylic acid, poly G; polyguanylic acid, poly I; polyinosinic acid, poly $C$; polycytidylic acid, poly $\mathrm{U}$; polyuridylic acid. 
骨格㬳および肝 RNase 標品：組織に 4 倍量の氷冷 $0.25 \mathrm{M}$ ショ榶水溶液を加え, ブレンダーで 5 分間ホ モジェナイズし，105,000× $\mathrm{g} 60$ 分間の遠心操作によ り得た上清を塐素標品とした. なお，骨格筋 RNase の部分精製はこの上清を用いて行った.

酻素活性の测定：(i) 遊離型 RNase 活性の测定 : 莱池 ${ }^{13)}$ の方法に準して行った. 標準条件は反応液 0.8 $\mathrm{ml}$ (4 mg tRNA, $125 \mathrm{mM}$ トリス一塩酸楥衝液 $\mathrm{pH}$ 7.5 および酻素液) とし, 10 分間 $37^{\circ} \mathrm{C}$ で反応させた のち，0.25\% 酢酸ウラニウムを含む $25 \%$ 過塩素酸 $0.2 \mathrm{ml}$ を加え混和して反応を停止した. 停止後 10 分 間承泠放置したのち沈殿物を遠心により除き，その上 清（酸可溶性画分）の一定量を水で 10 倍に希釈し， 波長 $260 \mathrm{~nm}$ における吸光度の上䄯を测定した. 比活 性は，蛋白欣 $1 \mathrm{mg}, 1$ 分間当りの波長 $260 \mathrm{~nm}$ におけ る吸光度の上界で表わした。なお，対照には，酢酸ウ ラニウムを含む過塩素酸混液を加えたのち醳素液を加 えたるのを用いた.（ii）全 RNase 活性の测定 : 不活 性 RNase を活性化するため p-chloromercuribenzoate (pCMB，終浐度 $1 \mathrm{mM}$ ) を反応液に添加し测定したも のを全 RNase 活性とした.

蛋白啠港度の测定：Lowry ら ${ }^{18)}$ による方法を用い， 結晶ウシ血清アルブミンを基準として求めた. カラム クロマトグラフィー溶出液の蛋白兵滦度は, 波長 280 $\mathrm{nm}$ における吸光度で求めた。

分子量の测定：Sephadex G-50を用いて Andrews ${ }^{17)}$ の方法に徒って行った. 標準蛋白質としてウ シすい䑏 $\alpha$-chymotrypsin (分子量, 21,600) $2 \mathrm{mg}$, ウ マ心䑏 cytochrome c (分子量, 12,300) $2 \mathrm{mg}$, ウシす い腈 insulin（分子量, 5,800) $10 \mathrm{mg}$ を用いた. 部分 精製醭素標品 $25 \mu \mathrm{g}$ および摽品蛋白倎を $40 \mathrm{mM}$ リ ン酸楥街液（pH 7.5）に溶解して全量を $1 \mathrm{ml}$ とした のち, あらかじ $40 \mathrm{mM}$ リン酸緩街液 ( $\mathrm{pH} \mathrm{7.5)} \mathrm{で}$ 平衡化した Sephadex G-50 カラム $(2.6 \times 61.5 \mathrm{~cm})$ に負荷し，同し楥衙液で流出した. 流出液は $2 \mathrm{ml}$ つ分画した. 標準蛋白梊のうち insulin は波長 $280 \mathrm{~nm}$ の吸収で, cytochrome c は波長 $414 \mathrm{~nm}$ の吸収で各ヶ 測定した. $\alpha$-chymotripsin は基梊として $\mathrm{N}$-acetyltyrosine ethylester を用い，基質の诚少を波長 $237 \mathrm{~nm}$ の吸収の減少から測定した. なお，標準蛋白所の chymotrypsin による消化は認められなかった.

\section{実験結果}

\section{1. 筋組織の RNase 活性とその inhibitor}

$$
\text { (405) }-19-
$$

筋組織の $20 \%$ ホモジェネート上清 $(105,000 \times \mathrm{g})$ について，標游条件で測定した場合， 7 回の測定値の 平均は遊離型 RNase 活性 ( $\mathrm{pCMB}$ 無添加時活性) では $0.11 / \mathrm{mg}$ of protein, 全活性 (pCMB 添加時活性) では $0.82 / \mathrm{mg}$ of protein であった。富田ら ${ }^{12,18)}$ の報 告した肝組織の RNase 活性值と比較すれば筋組織で は遊離型活性, 全活性共に著しく低いことがわかる。 遊離型活性は肝の約 $1 / 200$ である。また，富田らの結 果に従えば肝組織における遊離型活性と全活性との比 は約 0.92 であるのに対し，紡組織ではこの比が 0.13 である.すなわち、肝組織とは逆に筋組織では RNase の約 90\% が不活性な結合型として存在していること がわかる.

このことは，长野ら"1のいうように，不活性 RNase がある特定の阻害蛋白倎 (RNase inhibitor) との結 合物であるとするならば，筋組織では肝組織より RNase inhibitor の量が遊離型 RNase の量より相対 的に多いこと,さらに䇗組織には遊離型の RNase inhibitor の存在する可能性を示唆している.

この点をさらに確めるために, 部分精製した筋 RNase に対する筋ホモジェネート上清 $(105,000 \times g)$ の阻害効果を検討した. Fig. 1 に示すように,一定 量の管 RNase に箭上清を添加すると, 添加量に応じ て RNase 活性が阻害される. また, この阻害された 活性は $\mathrm{pCMB}$ を添加することにより復元する. さら に, 䇗上清のこの阻害効果は熱および酸処理により消

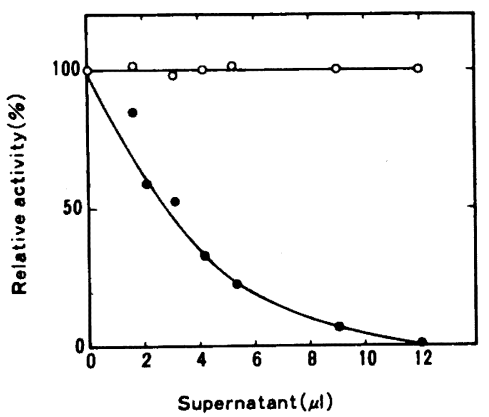

Fig. 1 Effect of supernatant from muscle homogenate on the activity of partially purified RNase

The indicated amount of supernatant $(105,000 \times \mathrm{g})$ was added to the reaction mixture. The activity measurements were made as described in the methods. The RNase activity measured in the presence of pCMB and absence of the supernatant was taken as $100 \%$. The RNase activity with $(O)$ and without (๑) $1 \mathrm{mM}$ pCMB. 
$-20-(406)$

失する、これらの結果から，筇上清には RNase を阻 害する蛋白兵性 inhibitor が遊離の状態で存在するこ とが推察される.他方，肝上清にはこのような阻害効 果は認められなかった。

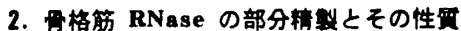

（1）肪 RNase の部分精製：上述の結果にもとう き，まず長野ら"゙の肝 RNase の精製方法に泮して肪 組織から不活性型 RNase を分別し，ついでこれを活 性化することによって RNase を部分的に精製するこ とを試みた，精製の各段階はナべて 0 4 ${ }^{\circ} \mathrm{C}$ で行っ た。

成熟ウシカエル骨格筋 $91.4 \mathrm{~g}$ に 4 倍量の $0.25 \mathrm{M}$

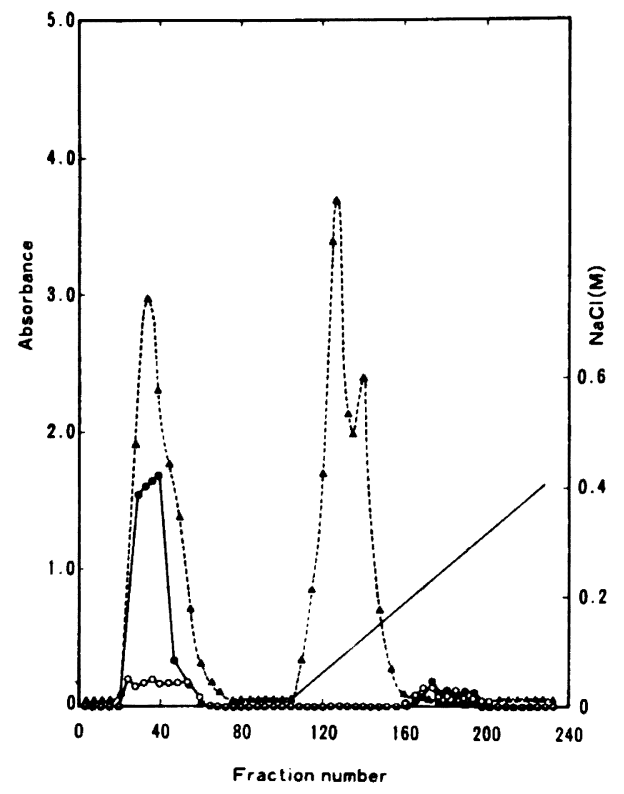

Fig. 2 CM-cellulose column chromatography of the free and latent forms of RNase in skeletal muscle extract

The supernatant $(355 \mathrm{ml})$ of $20 \%$ homogenate was applied to a CM-cellulose column $(3.3 \times 48 \mathrm{~cm})$ which was previously equilibrated with $10 \mathrm{mM}$ phosphate, $\mathrm{pH}$ 6.5. The column was washed with $2 l$ of the buffer and then developed with a linear gradient between $1.5 l$ volumes of the buffer and the buffer containing $0.6 \mathrm{M} \mathrm{NaCl}$. Fractions of $22 \mathrm{ml}$ were collected. The activity measurements were made with $0.2 \mathrm{ml}$ of each fraction. The RNase activity in the presence (-) and absence $(\mathrm{O}-\mathrm{O})$ of $1 \mathrm{mM} \mathrm{pCMB} ; \mathrm{NaCl}$ concentration (-); absorbance at $280 \mathrm{~nm}(\triangle-\cdots)$.
ショ桔水溶液を加えて的制したホモジェネートより， $105,000 \times \mathrm{g} 60$ 分間の遠心操作で $355 \mathrm{ml}$ の上清を分 画した。この上清をあらかしめ $10 \mathrm{mM}$ リン酸綏衙液 pH 6.5 で平衡化した CM-cellulose カラムに負荷し， 同し䌅衙液 $2 l$ で洗浄してから，10 mM リン酸緩衙 液 $\mathrm{pH} 6.5,1.5 l$ と $0.6 \mathrm{M} \mathrm{NaCl}$ を含む同し緩衝 液 $1.5 l$ からなる $\mathrm{NaCl}$ の直線港度勾配で蛋白梊の溶 出を行った. Fig. 2 は蛋白犋拉よび RNase 活性の 溶出曲線である。

遊辟型 RNase 活性はきわめて少なく, 非吸着部位 と $0.25 \mathrm{M} \mathrm{NaCl}$ による溶出部位とにわずかに热めら れるにすぎなかった．しかし，各 fraction に $\mathrm{pCMB}$ を添加して测定した场合，高い RNase 活性が非吸着 部位に银められた.長野ら“の結果からわかるように， 筋の不活性型 RNase は CM-cellulose クロマトグラ フィーに対し肝の不活性型 RNase と同し挙動を示す ことがわかった.

不活性型 RNase 分画 (約 $415 \mathrm{ml}$ ) を集め,これに pCMB（終浱度 $1 \mathrm{mM}$ ) を加え, $1 \mathrm{M}$ 第一リン酸ナト リウム溶液で $\mathrm{pH}$ を 6.5 に調節したのち，2 時間摚 拌して RNase の活性化を行った．ついでこの醭素夜 を CM-cellulose カラムに角荷し， $10 \mathrm{mM}$ リン酸緩 街液 $\mathrm{pH} 6.5$ 約 $500 \mathrm{ml}$ で洗浄し，非吸着部分を除い てから, 同し緩街液 $300 \mathrm{ml}$ と $0.5 \mathrm{M} \mathrm{NaCl}$ を含む絋

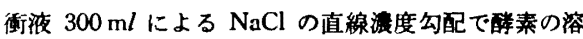
出を行った. Fig. 3 はその結果である. pCMBによ り活性化された RNase は $\mathrm{NaCl}$ 湌度約 $0.25 \mathrm{M} の$ 部位に溶出した。この RNase 溶出部位は Fig. 2 の 遊離型 RNase の溶出部位に一致し, 肝遊離型 RNase の溶出部位とも一致する.

各精製段階における純度ならびに回収率を Table 1 に示した. 回収率は 50\%, 純度は約 172 倍であっ

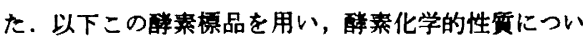
て肝 RNase との比較検討を行った.

（2）筋 RNase の性啠

i ）分子量：Fig. 4 は Sephadex G-50 によるゲ ルロ過法で RNase 䣼案暞品の分子量を検时した結果 である. Fig.に示したように RNase は cytochrome c と同し fractionに流出し，分子量は約 12,000 と算 定された。

ii）活性に対する $\mathrm{pH}$ およびイオン强度の影零： Fig. 5 a は筫 RNase の pH-活性曲線である。肝 RNase と同様，至適 $\mathrm{pH}$ は 7.5 付近である. また， 種々の RNase はその活性が高イオン強度下で㧕制さ 
Table 1 Purification of a RNase from bullfrog skeletal muscle

\begin{tabular}{l|c|c|c|c|c}
\hline \multicolumn{1}{c|}{ Purification step } & $\begin{array}{c}\text { Protein } \\
(\mathrm{mg})\end{array}$ & $\begin{array}{c}\text { Total activity } \\
\left(\mathrm{OD}_{\mathbf{8 0 0}}\right)\end{array}$ & $\begin{array}{c}\text { Specific activity } \\
\left(\mathrm{OD}_{\mathbf{3 0}} / \mathrm{mg}\right)\end{array}$ & $\begin{array}{c}\text { Purification } \\
\text { factor }\end{array}$ & $\begin{array}{c}\text { Recovery } \\
(\mathscr{6})\end{array}$ \\
\hline 20\% homogenate & $\mathbf{8 , 2 2 6}$ & $2,788(250)^{*}$ & 0.3 & - & - \\
$105,000 \times$ g supernatant & 3,017 & $2,627(200)$ & 0.9 & 1 & 100 \\
CM-cellulose (I) & 778 & 2,000 & 2.6 & 2.9 & 76 \\
CM-cellulose (II) & 8 & 1,395 & 174 & 193 & 53 \\
\hline
\end{tabular}

* without $1 \mathrm{mM}$ pCMB.

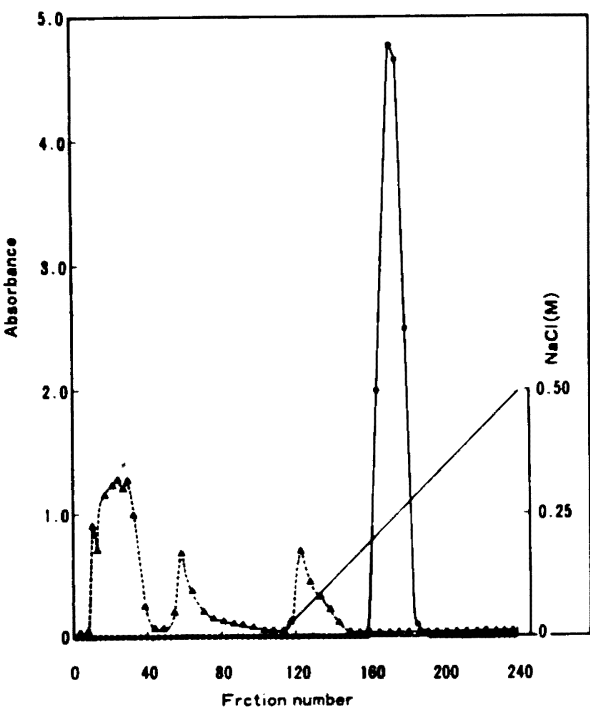

Fig. 3 CM-cellulose column chromatography of RNase activated with $\mathrm{pCMB}$

pCMB was added to the pooled fraction $(415 \mathrm{ml})$ to give a final concentration of $1 \mathrm{mM}$. After stirring for $2 \mathrm{~h}$ at $4^{\circ} \mathrm{C}$, the sample was applied to a CM-cellulose column $(2.2 \times 1.8 \mathrm{~cm})$. The column was washed with $500 \mathrm{ml}$ of the buffer and then was developed with a linear gradient between $300 \mathrm{ml}$ volumes of the buffer and the buffer containing $0.5 \mathrm{M} \mathrm{NaCl}$. Fractions of $5 \mathrm{ml}$ were collected. Activity measurements were made with $0.2 \mathrm{~m} l$ of each fraction. The RNase activity in the absence of $\mathrm{pCMB}$ as well as that in the presence of $\mathrm{pCMB}(-0) ; \mathrm{NaCl}$ concentration (-); absorbance at $280 \mathrm{~nm}(\Lambda-\Delta)$.

れることが知られている(115,18-20). 管 RNase も肝 RNase 同様高浱度 $\mathrm{NaCl}$ 存在下でその活性が阻害さ れ, さらに $\mathrm{pH}$-活性曲線は二相性となった. Fig. $5 \mathrm{~b}$ は筫 RNase 活性におよほす $\mathrm{NaCl}$ の影製を検討した 結果である。 0.3 0.4 M NaCl 存在下で活性は $50 \%$

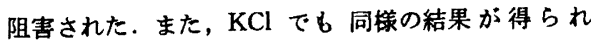
た.

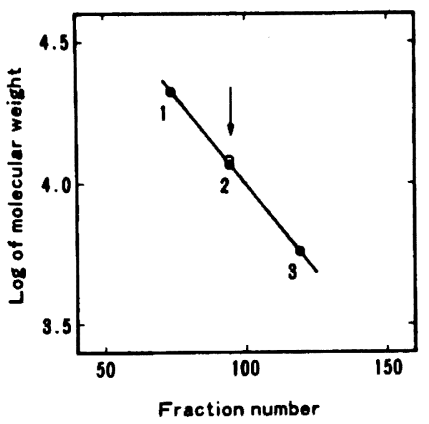

Fig. 4 Molecular weight determination of muscle RNase by gel filtration on Sephadex G-50

The sample containing RNase and marker proteins in total volumes of $1 \mathrm{~m} l$ was applied to a Sephadex G-50 column $(2.6 \times 61.5 \mathrm{~cm})$ and was developed with $40 \mathrm{mM}$ phosphate, $\mathrm{pH} 7.2$. The marker proteins used were $\alpha$-chymotripsin (1), cytochrome c (2) and insulin (3). Fractions of $2 \mathrm{~m} l$ were collected.

iii）安定性：Fig. 6 は醭素の安定性に対する $\mathrm{pH}$

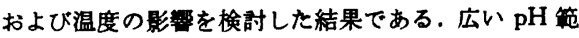
囲にわたって本醭素は安定であるが，アルカリ側で失 活した. また，種々の温度で前処理すると約 $60^{\circ} \mathrm{C}$ 以 上で急速な失活がおこる．また，この標品は縟縮し， $-20^{\circ} \mathrm{C}$ で保存すれば数力月間安定であった.

iv）金属イオンの RNase 活性に対する影整: Table 2 は RNase 活性に対する種々の金属イオン の影䇾を検討した結果である. $\mathrm{Cu}^{++}, \mathrm{Zn}^{++}, \mathrm{Hg}^{++}$, $\mathrm{Co}^{++}, \mathrm{Fe}^{+++}$によって佸性は阻害されたが，とくに $\mathrm{Zn}^{++}$の影雷は著しく, $0.1 \mathrm{mM}$ で 50\% の活性が阻 害された．EDTA による活性娍少は認められなかっ た.

v）㬳 RNase の作用形式と基梊特異性 : Fig. 7 は醉母 $\mathrm{t}$ RNA を基澌とした場合，加水分解物がいか なる大きさのものであるかを Sephadex G-25を用い たゲルロ過法で経時的に検討した結果である. 反応液 $2.1 \mathrm{ml}$ ( $3 \mathrm{mg} \mathrm{RNA}, 300 \mu \mathrm{mole} ト リ ス$ 一塩酸緩衙液 $\mathrm{pH} 7.5,3 \mu \mathrm{g} \mathrm{RNase)} \mathrm{を} 37^{\circ} \mathrm{C} て ゙$ incubate $し$, 所 

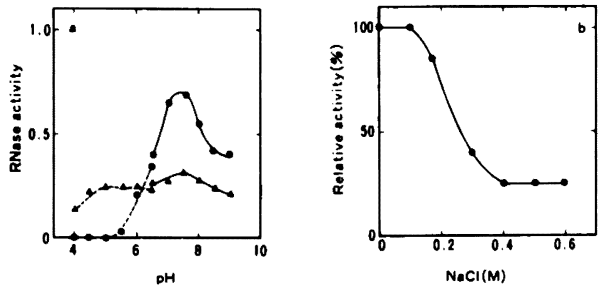

Fig. 5 a : Muscle RNase activity as a function of $\mathrm{pH}$ Acetate buffer $(50 \mathrm{mM}): \mathrm{pH} 4.0 \sim 6.5(\cdots)$ and Tris $\mathrm{HCl}$ buffer $(50 \mathrm{mM}): \mathrm{pH} 6.5 \sim 9.0(-)$ were used. The RNase activity in the presence $(\Delta)$ and absence (C) of $0.4 \mathrm{M} \mathrm{NaCl}$.

b : Effect of concentrations of $\mathrm{NaCl}$ on muscle RNase activity

The RNase activity was measured in $50 \mathrm{mM}$ Tris- $\mathrm{HCl}$ buffer, $\mathrm{pH} 7.5$, containing various concentrations of $\mathrm{NaCl}$.
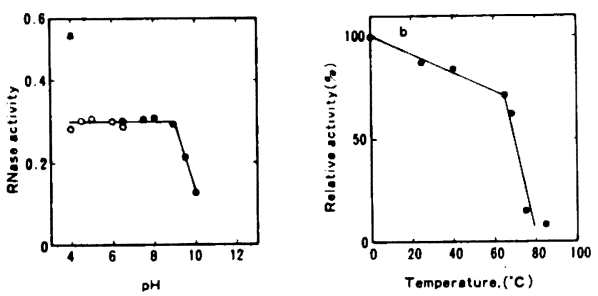

Fig. 6 Effect of $\mathrm{pH}$ and temperature on muscle RNase stability

a : RNase $(2 \mu \mathrm{g})$ was preincubated for $10 \mathrm{~min}$ in the buffer $(0.2 \mathrm{ml})$ of various $\mathrm{pH}$ at $37^{\circ} \mathrm{C}$. Acetate buffer $(50 \mathrm{mM}): \mathrm{pH} 4.0 \sim 6.5(\mathrm{O}-\mathrm{O})$ and Tris. $\mathrm{HCl}$ buffer $(50 \mathrm{mM}): \mathrm{pH} \quad 6.5 \sim 10.0(-)$ were used. After preincubation, the remaining activity was measured in the standard assay mixture.

b : RNase $(2.25 \mu \mathrm{g})$ was pretreated in $0.2 \mathrm{ml}$ of 50 $\mathrm{mM}$ Tris- $\mathrm{HCl}$ buffer, $\mathrm{pH} 7.5$, for $10 \mathrm{~min}$ at indicated temperature, and then the remaining activity was measured in the standard assay mixture.

要時間ごとに $0.4 \mathrm{ml}$ ずつ分別し, $100^{\circ} \mathrm{C} て ゙ ~ 1$ 分間 加熱して反応を停止した. 各試料 $(0.35 \mathrm{ml})$ は $0.3 \mathrm{M}$ $\mathrm{NaCl}$ を含む $10 \mathrm{mM}$ トリスー塩酸綏衝液 $\mathrm{pH} 7.5$ で 平衡化した Sephadex G-25 カラム $(1.6 \times 32 \mathrm{~cm})$ に 負荷し，同じ緩衝液で分解物の流出を行った。䋛軸は 波長 $260 \mathrm{~nm}$ の吸収，横軸は流出液量である. 未反応 RNA の吸収ピークは流出液量 $35 \mathrm{ml}$ 付近に認められ る.この吸収ピークは反応時間と共に低下したが，30 分間 RNase を作用させても monomerが流出すると予 想される部位には吸収は認められなかった。この結果 は， tRNA に対する筋 RNase の作用が endonuclease
Table 2 Effect of metal ions on the RNase activity

\begin{tabular}{l|c}
\hline Additionals & $\begin{array}{c}\text { Relative activity } \\
(\% 6)\end{array}$ \\
\hline None & 100 \\
$\mathrm{Zn}^{2+}$ & 2 \\
$\mathrm{Cu}^{2+}$ & 37 \\
$\mathrm{Hg}^{2+}$ & 42 \\
$\mathrm{Co}^{2+}$ & 64 \\
$\mathrm{Mg}^{2+}$ & 72 \\
$\mathrm{Mn}^{2+}$ & 82 \\
$\mathrm{Ca}^{2+}$ & 91 \\
$\mathrm{Ba}^{2+}$ & 95 \\
$\mathrm{Fe}^{2+}$ & 102 \\
$\mathrm{Fe}^{3+}$ & 63 \\
$\mathrm{Al}$ & 83 \\
EDTA & 111 \\
\hline
\end{tabular}

The assay was carried out under the standard conditions except that metal ion was added to the reaction mixture to a final concentration of $1 \mathrm{mM}$. All metal ions used were chloride salt.

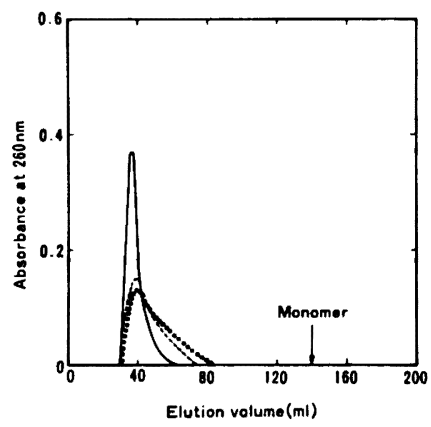

Fig. 7 Chromatography on a Sephadex G-25 column of muscle RNase reaction products

The reaction mixture $(2.1 \mathrm{ml})$ containing $3 \mathrm{mg}$ of yeast RNA, $3 \mu \mathrm{g}$ of RNase and $300 \mu$ moles of Tris$\mathrm{HCl}$ buffer, $\mathrm{pH} 7.5$, was incubated at $37^{\circ} \mathrm{C}$. An aliquot $(0.4 \mathrm{ml})$ of the reaction mixture was removed at the time indicated and after stopped the reaction by heating, was applied to a Sephadex G-25 column $(1.6 \times 32 \mathrm{~cm})$ equilibrated with $10 \mathrm{mM}$ Tris- $\mathrm{HCl}$ buffer, $\mathrm{pH} 7.5$, containing $0.3 \mathrm{M} \mathrm{NaCl}$. Elution was made with the same buffer containing $0.3 \mathrm{M} \mathrm{NaCl}$. Incubation was performed for $0 \mathrm{~min}(-), 3 \mathrm{~min}(\cdots)$ and $30 \mathrm{~min}(\cdots)$. Absorbance at $260 \mathrm{~nm}$ was automatically recorded on a $\mathrm{LKB}$ recorder attached to a Uvicord II UV absorptiometer.

作用であることを示している. なお， monomer の流 出部位は p-nitrophenol（分子量，136） $0.1 \%$ 水溶液 $0.35 \mathrm{ml}$ を用い決定した

Table 3 は合成 polynucleotide (poly A, poly G, 
Table 3 Activity of the RNase for synthetic polynucleotides

\begin{tabular}{c|c}
\hline Substrate & Relative activity \\
\hline tRNA & 1.0 \\
poly G & 0.0 \\
poly A & 0.0 \\
poly I & 0.05 \\
poly C & 0.55 \\
poly U & 3.10 \\
\hline
\end{tabular}

The RNase activity was assayed under the standard conditions.

poly I, poly C, poly U) に対する RNase の分解能 を検郡した結果である.醉母 tRNA を基啠とした時 の活性を 1 として, 各 polymer に対する活性を相対 活性として示した。 poly U および poly C は水解さ れ，polyUに対してはとくに高い活性が恝められた.

\section{考察}

笳組織における RNase の報告は少ない。しかし， Goldspink $5^{20)}$, Abdullach ら ${ }^{21)}$ および Meyer ${ }^{22)}$ は ヒトの, Tappel ら 28.20) はマウスおよびニワトリの骨 格筋について, いくつかの RNase が存在する可能性 のあることを報告している. 著者はカエル管組織の中 性域に至適 $\mathrm{pH}$ を有する RNase について検討した. しかし，それがー種類であるかいなかについては明ら かにすることができなかった.

カエル筋組織上清分画のこの RNase は, 遊離型が きわめて少なく大部分不活性な RNase-RNase inhibitor 結合体として存在し, 大部分遊離型である力 エル肝とは対照的である。また，筋組織上清には，筋 RNase を阻害する RNase inhibitor が遊離の状態で 存在することを示唆する結果を得たが,この遊離の inhibitor 量は，部分精製した筋 RNase 標品 $1.9 \mu \mathrm{g}$ （活性，0.3）を $50 \%$ 阻害する阻害活性を 1 単位とす ると，筋 $20 \%$ ホモジェネート上清 $1 \mathrm{~m} l$ 中に約 300 単位存在することになる. RNase inhibitor について は, 種々の動物組織においてその存在が報告10 22, 28 28) されているが，その生理的意義についてはまだ不明の 点が多い. カエルの場合肝組織に比較して筋組織には かなりの量の遊離 RNase inhibitor が存在すること を認めたが,このことの意味は今後の研究課題である. この実体については，最近その精製に成功したので別 に報告する.

部分精彆した筋 RNase の性質は，検討した範囲で

$$
\text { (409) }-23-
$$

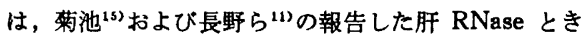

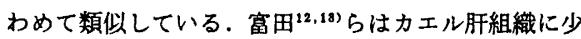
なくとも四種類の RNase が存在すると報告している が，著者が今回得た筋 RNase がそのいずれに相当す るかはまだ明らかではない。

\section{結論}

カエル骨格筋上清分画に存在し, 至適 $\mathrm{pH}$ を中性域 に有する RNase について検討した結果, 次の結論を 得た。

1） RNase の大部分は RNase inhibitor と結合し て不活性な状態で存在し，遊離型 RNase は著しく少 ない.

2）骨格筇上清分画には，遊離の RNase inhibitor が存在する。

3）部分精製した骨格笳 RNase の性澌は肝 RNase のそれと類似する.

本研究を行うにあたり，協力していただいた教室員各位， ならびに 東京大学栄美学教室長野弘講師に深く感䝰いたしま †.

\section{文献}

1) McDonald, M.R. : Ribonucleases. Methods in Enzymology, 2, 427 436, 1955.

2) Roth, J.S. : Some observation on the assay and properties of ribonuclease in normal and tumour tissues. Methods of Cancer Research, 3, 153 242, 1967.

3) Barnard, E. : Ribonucleases. Annual Review of Biochemistry, 38, 677 732, 1969.

4) Sierakowska, H., and Shugar, D. : Mammalian nucleolytic enzymes. Progress in Nucleic Acid Research and Molecular Biology, 20, 59 130, 1977.

5) de Lamirande, G., Allard, C., de Costa, H.C., and Cantero, A. : Intracellular distribution of acid and alkaline ribonuclease in normal rat liver. Science, 119, 351 353, 1954

6) Rahman, Y.E. : Existence of a third ribonuclease in rat liver particulates. Biochim. Biophys. Acta, 119, 470 479, 1966.

7) Rahman, Y.E. : Studies on rat liver ribonucleases, I. Intracellular localization of the alkaline ribonuclease. Biochim. Biophys. Acta, 146, 477 483, 1967.

8) Rahman, Y.E. : Studies on rat liver ribonuclease, II. Zonal centrifuge of acid ribonuclease, implication for the heterogeneity of lysosomes. Biochim. Biophys. Acta, 146, 484 492, 1967.

9) Bartholeyns, J., Peeters-Joris, C., Reychler, H., and Baudhuin, P. : Hepatic nucleases, I. Methods for 
$-24-(410)$

the specific determination and characterization in rat liver. Eur. J. Biochem., 57, 205 211, 1975.

10) Baudhuin, P., Peeters-Joris, C., and Bartholeyns, J. : Hepatic nucleases, II. Association of polyadenylase, alkaline ribonuclease and deoxyribonuclease with rat liver mitochondria. Eur. J. Biochem., 57, 213 220, 1975.

11) Nagano, H., Kiuchi, H., Abe, Y., and Shukuya, R. : Purification and properties of an alkaline ribonuclease from the hepatic cytosol fraction of bullfrog, Rana catesbeiana. J. Biochem., 80, 19 26, 1976.

12) Tomita, Y., Goto, Y., Okazaki, T., and Shukuya, R. : Liver ribonucleases from bullfrog, Rana catesbeiana, purification, properties and changes in the activity during metamorphosis. Biochim. Biophys. Acta, 582, 504 514, 1979.

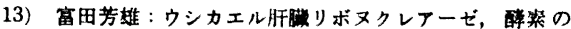
梢製，性莫，分布および变怒期に㧍ける变化について。 日医大誌, 46, 79 90, 1979.

14) Kirby, K.S. : A new method for the isolation of ribonucleic acids from mammalian tissues. Biochem. J., 64, 405 408, 1956.

15）彝池恭一：ウシカエル肝腈 ribonuclease の粩製とその 性畝について。 日医大誌，39，365～408, 1972.

16) Lowry, O.H., Rosebrough, N.J., Farr, A.L., and Randall, R.J. : Protein measurement with the Folin phenol reagent. J. Biol. Chem., 193, 263 275, 1951

17) Andrews, P. : The gel-filtration behavior of proteins related to their molecular weight over a wide range. Biochem. J., 96, 595 606, 1965.

18) Futai, M., Miyata, S., and Mizuno, D. : Acid ribonuclease of lysosomal and soluble fractions from rat liver. J. Biol. Chem., 244, 4951 4960, 1969.

19) Goto, S., and Mizuno, D. : Degradation of RNA in rat reticulocyte, 1. Purification and properties of rat reticulocyte RNase. Arch. Biochem. Biophys., 145, 64 70, 1971.
20) Goldspink, D.E., and Pennington, R.J. : A ribonu clease from human skeletal muscle. Biochem. J.. 118, 9 13, 1970

21) Abdullach, F., and Pennington, R.J. : Ribonuclease activity in normal and dystrophic human muscle. Clin. Chim. Acta, 20, 365 371, 1968.

22) Meyer, W.L. : Ribonuclease inhibitor system abnormality in dystrophic mouse skeletal muscle. Science, 170, 747 749, 1970.

23) Tappel, A.L., Zalkin, H., Caldwell, A., Desai, I.D., and Shibko, S. : Increased lysosomal enzymes in genetic dystrophy. Arch. Biochem. Biophys., 96, 340 346, 1962.

24) Tappel, A.L., Sawant, P.L., and Sibko, S. : Lysosomes: Distribution in animals, hydrolytic capacity and other properties. "Lysosomes" (A.V.S. de Reuth and M.P. Camereon, eds), p. $78 \sim 113$, Churchill, London, 1963.

25) Shortman, K. : Studies on cellular inhibitors of ribonuclease, I. The assay of the ribonuclease inhibitor system, and the purification of the inhibitor from rat liver. Biochim. Biophys. Acta, 51, 37 49, 1961.

26) Takahashi Y., Masse, K., and Suzuki, Y. : Purification and characteristics of RNase inhibitor from pig cerebral cortex. J. Neurochem. 17, 1433 1440, 1970.

27) Blachburn, P., Wilson, G., and Moore, S. : Ribonuclease inhibitor from human placenta, J. Biol. Chem., 252, 5904 5910, 1977.

28) Shortman, K. : Studies on cellular inhibitors of ribonuclease, III. The levels of ribonuclease and ribonuclease inhibitor during the regeneration of rat liver. Biochim. Biophys. Acta, 81, 50 55, 1962.

29) Gribnau, A.A.M., Schoenmakers, J.G.G., and Blomendal, $\mathrm{H}$. : Purification of rat liver ribonuclease inhibitor and its effect on polyribosomes integrity. Arch. Biochem. Biophys., 130, 48 52, 1967.

(受付: 1979 年 4 月 26 日) 